\title{
Serbia and Integration Processes in the Balkans
}

\author{
Dejan Šabić', Mila Pavlović', Rade Davidović \\ Received: January 2008 | Revised: September 2008 | Second Revised: February 2009 | Accepted: February 2009
}

\begin{abstract}
The aim of these analyses is to identify both the components of the geographical position of Serbia, which determine the interregional connections in the Balkans and the causes, based on low level of integration, which are mainly the result of anthropogenic factors. As situated between the Western and Central Europe, the Southeastern Europe and the Middle East, Serbia constantly develops its connections to make itself a gateway for these regions. Due to unfavorable political situation in the last decade of the 2oth century, Serbia could not plan corridors within the future enlarged European Union. Serbia is expected to do much in the following period on the political and economic plan. Its physical and geographical position and transportation corridor network are the starting points in the realization of the aim. According to the fact that the European commission started a series of projects on the integration of the European Union in the last decade of the 2oth century, the collaboration among the countries of the region should develop on national, regional, and particularly local level in order to motivate the citizens to participate in processes and directly benefit from the developing policy and integrating processes.
\end{abstract}

Key words: Serbia, Balkans, development, corridors, integration, processes

\section{Introduction}

The development of the integration idea is one of the basic starting points of the South-eastern European countries in the process of political and economic transition. The Balkan countries integration is induced by European experiences as well as by the processes of the European and world capital, which are the results of the globalization processes. The aim of the integration is more rapid growth of all Balkan countries, ready to open their markets. Regardless of the transition process lagging behind, the integration is also stimulated in Serbia and defined as a strategy of Serbia's extensional development since 1996 when the Extensional Plan of Serbia was passed on. Concerning the future prospects of the former communist societies in transition (including most countries in South-East Europe), politicians and economists saw a positive economic development and believed the post-socialist nations would rapidly catch up with western economic structures (Göler, 2005). Until 2000, the Balkan countries started reforms in more dynamic way comparing to Serbia, also using the experience of the developed European countries. The starting principles of Serbia's defined development should be in accordance to the strategy of the general European extensional development (INTERREGIA, VISION PLANET, ESDP, etc).
The major challenges are the economic recovery of the Balkans and the integration of all the countries of the region into European system. These countries are facing with the fundamental problems of drastic productive capacity decrease and disappearance, regional market reduction and high level of investment risks. We argue that while the standard recipes for liberalisation and monetary stabilisation - need to be applied, they will not be effective unless accompanied by fiscal reform, public investment and micro-economic restructuring.

As the experience of transition clearly illustrates, the key issue is precisely the one of rebuilding the economic base of the Balkan countries. Macroeconomic stability, by itself, cannot accomplish the process of restructuring and modernisation that these economies must undergo in order to become internationally competitive. In fact, in some cases, good short term macroeconomic indicators, e.g. price and exchange rate stability, tend to disguise serious mismanagement of these countries. Effective enterprise restructuring is the key to strong growth and exports, and a set of policies supportive of these processes must be included in any programme of the reconstruction (Gligorov, 1999).

\footnotetext{
University of Belgrade, Faculty of Geography, Studentski trg 3/3, 11.000 Belgrade, Serbia; sabic@gef.bg.ac.yu

2 University of Novi Sad, Faculty of Science, Department of Geography, Tourism and Hotel Management, Trg Dositeja Obradovića 3, 21000 Novi Sad, Serbia;
} 


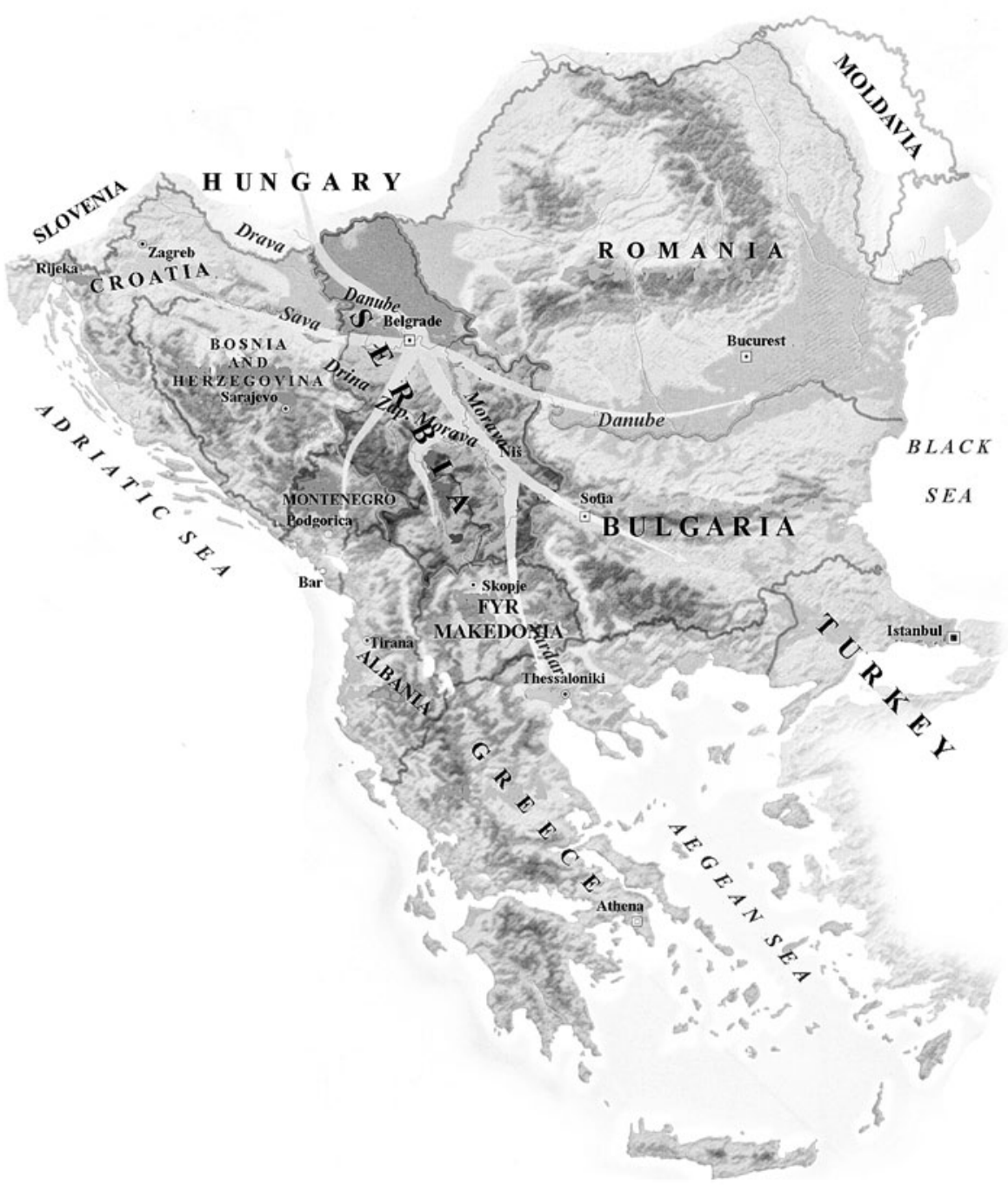

Figure 1. Main traffic routes across Serbia (adapted map from Šehić D. 2007 Source: Atlas of Serbia. Monde Neuf, Beograd, 18 pp. (in Serbian)

\section{Aspects of geographical position of Serbia}

Serbia is the Balkan, Danube and Central European country (Voivodina is situated north from the northern Balkan borders - the Danube). It is situated with $75 \%$ of its territory in the Balkans, while $25 \%$ belongs to the Pannonian plain. The total area of Serbia is $88.361 \mathrm{sq} \mathrm{km}$, while the population is 9.9 million.

Concerning geotectonic terms, the Balkan part of Serbia is divided (by tectonic movements) into mountain ranges and deep valleys leading the rivers into three different confluences: the Danube (the Black Sea), Aegean and Adriatic confluence. The Balkan Peninsula has the shape of a reversed irregular triangle, which is leant on the continental block by its basic side of the parallel direction. The triangle is divided into eastern and western part (the line Smederevo-Stalać-Niš-Vranje-Preševo-Skopje-Veles-Thessalonica) by the Morava-Vardar valley, which is of the meridian direction (Pavlović, 1998).

The Nišava valley, as a part of the Nišava-Marica valley is an important traffic corridor, connecting Niš and Istanbul via Sofia. The Balkans is connected with Eastern Europe and Russia through the eastern part, dominated by Bulgarian territory, while through the western one (where the cen- tral part of Serbia is) it is connected with Western Europe (Šabić, Pavlović, 2005).

The alternative to the Morava-Vardar traffic corridor is the direction Kolubara-Ibar-Kosovo, which is of no great importance due to political situation in Kosovo and $\mathrm{Me}$ tohia. The potential important traffic corridor is the Trans Balkan main road leading from Prahovo at the Danube, through the Timok basin to Niš along the Toplica valley, across Kosovo and Metohia, along the Drim valley to Skadar which helps connecting the Danube region to the Adriatic Sea. That direction has never become really important due to political situation after 1948 (Pavlović, 1998). Therefore, it was replaced by the other direction along which runs one of the most important railroad lines of Serbia: Belgrade-Bar (Belgrade-Valjevo-Požega-Užice-PrijepoljePodgorica-Bar) (Grčić, Ratkaj, 2003).

The connection is established between the cities along the Zapadna Morava valley with the valleys of meridian direction (the Morava-Vardar valley and the Drina valley). By its northern parts (Voivodina and Peripannonian Serbia), Serbia is opened towards the Pannonian plain, i.e. towards the European Union countries - Hungary, Austria, Slova- 
kia, Czech Republic and others (through the traffic junctions of Budapest and Vienna).

The potential significance of the Danube position increased after building the Danube-Main-Rain canal, in 1992, thus establishing the waterway from the North Sea to the Black Sea. The Sava and Tisa rivers are parts of the important waterway net. The Sava was the longest river of the former Yugoslavia and nowadays it is the international river, which springs in Slovenia, runs through Croatia, Bosnia and Serbia and flows into the Danube. The Tisa is the international river, along which smaller ships flow through Romania, Hungary and Serbia.

There are several natural: biological, ecological (forests and steppes), hydrographic, historical (the long lasting Turkish influence at the south and the Austrian-Hungarian at the north) and other influences on the territory of Serbia. Since situated among the Western and Central Europe, the Southeastern Europe and the Middle East, Serbia constantly develops its roads, railway and waterway connections to make itself a gateway for these regions. Due to unfavorable political situation in the last decade of the $20^{\text {th }}$ century, Serbia could not plan traffic corridors within the future enlarged European Union (Šabić, Pavlović, 2008).

Beside the traffic connections, the political borders have also been formed in the Balkans. By disabling communication, these borders have isolation and parting function. Resulting from all that Serbia was isolated from the main development streams for centuries, having a difficult role of the Euro-Asian Bridge between the Eastern and Western Empires. The influences of the Hapsburg Monarchy and Turkey were very important for the quality of the traffic net in Serbia, that is, the country was subordinated to the empires interests. Advancing the connections with the neighboring countries is one of the directions in the traffic development of Serbia. The prerequisite of the Serbian integration into the European Union is to have the traffic infrastructure built according to the European standards. By the Extensional Plan of the Republic of Serbia of the year 1996, the following highway-traffic corridors were established: Hungarian borderSubotica-Novi Sad-Belgrade (E-75). Further directions lead from there: Belgrade-Niš-Skopje-Athens (E-75), Niš-Dimitrovgrad-Sophia-Istanbul (E-80) and Belgrade-Bar (E-763); corridor Niš-Peć-Priština-Čakor, the connection with the highway Belgrade-Bar (E-8o), corridor the Croatian borderBelgrade-Vršac-Romania (E-8o), the Zapadna Morava corridor Pojate-Varvarin-Kruševac-Kraljevo-Čačak (E-761). As the railway traffic concerned, the fast railroad projections are of great significance on the following lines: Hungarian border-Subotica-Belgrade-Niš-Preševo-the border of FYR of Macedonia (E-85, E-70), Belgrade-Pančevo-Vršac-Romanian border (E-66), Niš-Dimitrovgrad-Bulgarian border (E-70), and Belgrade-Šid-Croatian border (E 70). The railway net of Serbia is characterized by insufficient rail electrification, a substantial part of one-track railroads and old vehicles. Traffic advancement demands huge material investments so they have to be directed towards the most perspective directions where their economical justification can be expected.

Ports are the basic part of the waterway traffic development: Belgrade, Pančevo, Novi Sad, and Prahovo (Šabić,
Pavlović, 2005). The international river traffic is directed towards the Danube, that is, towards the Danube-MainRhine corridor. One of the primary aims of normal international sailing along the Danube is cleaning its river bed and rebuilding the bridges destroyed in 1999, first of all the bridges of Novi Sad and Ostružnica (Grčić, Ratkaj, 2006). As air traffic concerned, there are plans for the reconstruction of Belgrade airport (Surčin), Niš airport (Tzar Constantin) and the one in Priština, as well as for the modernization of old information systems and navigation equipment (Šabić, Pavlović, 2008).

Integration becomes a very difficult task when the units, which are to be approximated to each other, are different in many crucial areas such as economic structure, standard of living, social conditions and demographic characteristics. Differentiation is great within the Balkan countries, as a result of various factors: geographical, historical, economical, political, social, demographical, etc.

Two confronted processes are evident on the political map of the Balkan Peninsula, but both mutually interde pendent. The first process is territorial disintegration, and the other one is the process of economic integration and collaboration. These processes reflect on the spatial and functional changes of the border regions. Economical integration is the most important prerequisite for establishing and developing the various forms of international contacts and relations among the Balkan countries.

Territorial differentiation of the Balkan borders is given, depending on the scale of border closeness, the points of contact and filtering functions. The cross-border cooperation depends on landscape, cross-border communications and on the whole economic terms in Europe, but above all it depends on political good will of the Balkan countries. They have different examples of borders - from front-borders to modern bridge-borders (Grčić, Ratkaj, 2006).

The Balkan countries did not establish the collaboration, and the main reason lies in the lengthy cold war and contradictions of the past. The differentiation reflects diversity in terms of the status, sovereignty and legitimacy of the authorities in the Balkans, which in turn affects the ability of countries to meet the conditions. The region encompasses self-governed states such as Serbia and Montenegro, Croatia, and Albania, international protectorates such as Bosnia-Herzegovina, and semi-protectorates (FRY Macedonia). Such differentiation contradicts promoted degrees of the cooperation in the region (Stojkov, 2000). Many Balkan countries tend to regard regional schemes with suspicion, they can bring that they contradict the principal goal of European integration.

The European Union tries to establish the unique framework of relations with the Balkan countries. This a priori differentiation is at the root of the varying progress in bilateral relations with the European Union, which in turn exacerbates local disparities. The peace agreement in FRY Macedonia, the end of the constitutional deadlock in Serbia and Montenegro, the settlement of the Prevlaka dispute and the peace-keeping in Bosnia-Herzegovina and FRY Macedonia demonstrate the substantial European Union leverage in the region and heavy use of political conditionality. The most recent example of the friendly relation im- 
provement is the termination of the visa regime among Serbia, Montenegro and Croatia and the possibility of crossing the Bosnian and Serbian border without passport, but with the personal ID card only.

The process of integration in the Balkans has not paid enough attention to local societies nor has it strengthened the capacity of national authorities to respond the needs of citizens. The actual speed of changes has raised some questions as to whether it is fair to ask new market economies to incorporate changes that even current member countries are struggling to incorporate.

\section{Serbia and Integration Processes in the Balkans}

Considering the fact that integration processes are the inevitability and the need of the modern world every country in the world should aspire to, Serbia is expected to do a lot in the following period on the political and macroeconomic plan in order to achieve that aim. The starting point of the aim to get realized is its physical and geographical position and transportation corridor network. The European commission started the whole series of projects and initiations related to the integration and expansion of the European Union in the late $20^{\text {th }}$ century (in Crete, 1994, in Helsinki, 1997). The majority of pan European corridors' projects towards the east and the southwest of Europe are the concern of our country (Pavlović, Šabić, 2007).

The absence of Serbia at conferences in Crete and Helsinki influenced the permanent effects on the location of the pan European corridors in the Southeast Europe. Beside the fact that Serbia, as a central Balkan country, has promisingly good geographic position and by comparing the components of the position with the neighboring Balkan countries, the importance of its position is not adequately estimated.

The concept of trans-European transport corridors arose after the fall of the Berlin Wall. They are meant to facilitate the exchange of goods, persons, oil and other energy supplies, and telecommunication systems between Europe and the Balkan countries (Šabić, Pavlović, 2008).

The starting basis in the further integration process es of our country and the region countries is supposed to be founded on passing the laws and sub-acts, according to which the country will be divided in space -functional regions, carried out the strong decentralization of the country and formed the powerful central poles of growth. Regarding the fact that Serbia was isolated from the international political scene in the last decade of the $20^{\text {th }}$ century and the population has become impoverished, a longer period of time is necessary for Serbia than for other neighboring countries to join the processes of integration. It does not only depend on our wishes, but on our possibilities, too. Although Serbia is the Balkan and central European country, and the Danube and Morava also, which makes it geographically significant since it presents the link between Central and Western Europe and the southeast of the continent and Near East, it still has not succeeded to expose geographical position and significance in an adequate way, with arguments, in the right place and in the right moment even though it might have been the most important thing for the future of this country. Why do we point this out? Because we are of the opinion that establishing the transportation corridor' network enables easier circulation of merchandise, passengers, capital and information by which the integration lines of transportation are simplified and speeded up. That includes balancing the quality and the regime of transportation services and also the simplification of the border procedure. In a word, the establishing of the pan European network provides the functional interregional connection, which means better living conditions for people within its integral parts with the purpose of providing the physical integration of the eastern and central areas of the continent.

We consider that there are certain limitations in the functioning of the pan European corridors VII and X. The corridor VII is a sole European corridor, which has basically the river course, and it is a part of a singular trans-European waterway Danube-Main-Rhine. The potentials of this corridor are scarcely exploited, especially downstream from Budapest. The existence of corridor directed from Budapest, via Carioca and Sofia to Thessalonica is disputable because it has far more complex physical and geographical predispositions of terrain, worse infrastructure and it is longer regarding the corridor XX (with the branch A) in direction Budapest-Belgrade-Niš-Skopje-Thessalonica (Šabić, Pavlović, 2008).

If the principle of functional complementarities and transport corridors integration is obeyed, the corridor IV (more exactly, the given section of the corridor), which has a competitive position with regard to the corridor $\mathrm{X}$, is completely needless.

Great importance have to be given to regional development strategies, which include the construction of adequate regional line of communication and all with the aim of avoiding the loading metropolitan regions and creating the comparative advantages in other poles of development. Serbia has been given a certain importance in transportation, and Belgrade the status of the hub. Good position of transportation lines and connection with the main European source - Budapest, to which Belgrade is connected by the branch $\mathrm{A}$ of corridor $\mathrm{X}$, gives it the primary significance in connecting the European Union with other Balkan countries. The important corridors of the air traffic between the west and central parts of Europe and the Southeast Asia lead across the Balkan air territory (Stojkov, 2000). The shortest and economically justified connections toward the Southeast Asia lead across Serbia's air territory and the most important airport in Serbia is the Belgrade one with six million passengers per year.

\section{Spatial-functional regionalization of Serbia in the function of integration processes in the Balkans}

Since the beginning of the $21^{\text {st }}$ century, political role of borders in the Balkan countries has changed. Gradually, they are transformed from barriers to zones of bilateral or multilateral cooperation. The initial role in the spatial-functional integration among the Balkan countries ought to be taken 
Table 1 Basic statistical data of main administrative units in Serbia

\begin{tabular}{|c|c|c|c|}
\hline Name of administrative unit & $\mathrm{P}\left(\mathrm{km}^{2}\right)$ & Number of settlements & Population in 2002 \\
\hline Serbia & 88,361 & 6,155 & * 7,498,001 \\
\hline Central Serbia & 55,968 & 4,239 & $5,466,009$ \\
\hline Voivodina & 21,506 & 467 & $2,031,992$ \\
\hline Kosovo and Metohia & 10,887 & 1,449 & ? \\
\hline
\end{tabular}

* Population without Kosovo and Metohia

Source: Republic Statistical Office, 2003

by regional units, which could be formed in the zones of increasing contacts among border zones. Their task would be to help increase the transparency of borders among countries in the Balkans, knowing that the borders robust barrier for any intensification of the development, intraregional or interregional linking either.

Basic statistical data are summarized in Table 1. Serbia $\left(88,361 \mathrm{~km}^{2}, 6,155\right.$ settlements; population $7,498,001$ in 2002) consists of three administrative, historically different parts: Central Serbia $\left(55,968 \mathrm{~km}^{2}\right.$, 4,239 settlements, pop- ulation 5,466,009), Voivodina $\left(21,506 \mathrm{~km}^{2}, 467\right.$ settlements, population 2,031,992) and Kosovo and Metohia $\left(10,887 \mathrm{~km}^{2}\right.$, 1,449 settlements). In spatial and functional sense, Serbia includes 30 regions (Table 2 ).

The above mentioned spatial and functional regional division in Serbia does not reflect the actual field status. It is more political and less functional regionalization. Therefore it is necessary to make methodologically more complex spatial re-organization that would incorporate all aspects of the nature-population-economy-settlement-

Table 2 Basic statistical data of regions in Serbia

\begin{tabular}{|c|c|c|c|c|}
\hline Region & Area $\left(\mathrm{km}^{2}\right)$ & Municipalities & Settlements & Population \\
\hline Beograd & 3,224 & 16 & 157 & $1,576,124$ \\
\hline Severno-bački & 1,784 & 3 & 45 & 200,140 \\
\hline Srednje-banatski & 3,256 & 5 & 55 & 208,456 \\
\hline Severno-banatski & 2,329 & 6 & 50 & 165,881 \\
\hline Južno-banatski & 4,245 & 8 & 94 & 313,917 \\
\hline Zapadno-bački & 2,420 & 4 & 37 & 214,011 \\
\hline Južno-bački & 4,016 & 12 & 77 & 593,666 \\
\hline Mačvanski & 3,268 & 8 & 228 & 329,695 \\
\hline Kolubarski & 2,474 & 6 & 218 & 192,204 \\
\hline Podunavski & 1,248 & 3 & 58 & 210,290 \\
\hline Šumadijski & 2,387 & 7 & 174 & 298,778 \\
\hline Braničevski & 3,865 & 10 & 189 & 200,503 \\
\hline Sremski & 3,486 & 7 & 100 & 335,901 \\
\hline Pomoravski & 2,614 & 6 & 191 & 227,435 \\
\hline Borski & 3,507 & 4 & 90 & 146,551 \\
\hline Zaječarski & 3,623 & 4 & 173 & 137,561 \\
\hline Zlatiborski & 6,140 & 10 & 438 & 313,396 \\
\hline Moravički & 3,016 & 4 & 206 & 224,772 \\
\hline Raški & 3,918 & 5 & 359 & 291,230 \\
\hline Rasinski & 2,668 & 6 & 296 & 259,441 \\
\hline Nišavski & 2,729 & 9 & 282 & 381,757 \\
\hline Toplički & 2,231 & 4 & 267 & 102,075 \\
\hline Pirotski & 2,761 & 4 & 214 & 105,654 \\
\hline Jablanički & 2,769 & 6 & 336 & 240,923 \\
\hline Pčinjski & 3,520 & 7 & 363 & 227,690 \\
\hline Kosovski & 3,117 & 10 & 393 & $?$ \\
\hline Prizrenski & 1,910 & 4 & 220 & ? \\
\hline Pećki & 2,450 & 5 & 337 & $?$ \\
\hline Kosovsko-mitrovički & 2,050 & 6 & 335 & $?$ \\
\hline Kosovsko-pomoravski & 1,412 & 4 & 184 & $?$ \\
\hline
\end{tabular}


function development respecting the political situation in the Balkans and the integrating processes in Europe (Šabić, Pavlović, 2008).

The first problem of the regionalization in Serbia relates to Kosovo and Metohia. According to the current administrative division of Serbia, there are five districts in Kosovo. The Serbian Parliament has established this division but it is unreal, because Kosovo has been under the United Nations jurisdiction since 1999 and the majority of the Albanian people do not acknowledge the Serbian sovereignty over the southern province or its district division. Serbian and other non Albanian people who lived in Kosovo until 1999, were the only one who respected this spatial-functional division and its legal authorities, but today they are minority there (over 100,000 non Albanian people migrated into Serbia after UNMIK - Interim Administration Mission in Kosovo arrival). As a conclusion to the situation in Kosovo, it might be said that there is not a real guarantee of the standards imposed by the UNMIK and no reality-related validity of the principle of "standard before status" (Brujan, 2005). Although Kosovo Albanians self-proclaimed Kosovo independence in 2008 , such action could seriously affect the whole regions, taking into consideration that the international low is violated because one national minority self-proclaimed the independence of the territory in the independent state, the United Nations member with internationally acknowledged borders. This kind of legitimating would have to be also granted for instance to Serbs in Bosnia and Herzegovina or to Albanians in Macedonia and in general to all areas where a minority at state level represents a majority on a regional level. Proceeding from all mentioned, the authors of this paper consider that by further negotiations between Serbian and Albanian sides the existing political crisis on the standards and status of Kosovo and Metohia could be exceeded. The present status of Kosovo and Metohia is not good, neither for the Serbian nor for the Albanian people because it violates the international law and endanger the situation of other non Albanian population of this southern Serbian province (Pavlović, Šabić, 2007).

The second problem relates to the Raška region, the so called Sanjak region (named after the administrative-political unit of the former Turkish Empire). The Raska region consists of Zlatibor (Nova Varoš, Priboj, Prijepolje, and Sjenica) and Raška district (Novi Pazar, and Tutin). The Raška region or Sanjak region is actual historical, ethnological, geographical and sociological entity and being divided into two districts it has separated the local, mainly Muslim population. It is, therefore, necessary to carry out a re-division of this part of Serbia and re-connect its people into unique spatial-functional aggregation. Although the administrative division separates the people of Raška region, they gravitate to Novi Pazar, the biggest economical, demographical, cultural, and university center of the region.

The third problem relates to Voivodina, earlier called "the breadbasket of Europe", which could feed half a Europe. Its indeed remarkable natural resources, above all its conserved soil quality and surface and subterranean water resources, higher economical level than the other parts of Serbia enable the creation of the solid foundation for devel- oping the collaboration with other European regions. This is just the first step in the future integration development of this region into the system of the European regions. In order to accelerate the integration of this part of Serbia into economically steady European region society, it is necessary to provide the legal basis and its conditional independence.

According to the new spatial division, by the decentralization of Serbia and its both spatial and functional entity, it is planned to accomplish the economical integrity of its component parts that would provide better life quality for citizens, especially considering economy and transport.

\section{Conclusion}

More intensive interest of the Serbian geographic science in problems of integrating process in the Balkans dates from the early 9o's. Due to economic isolation and disintegration in the former Yugoslavia of the 9o's, the interest in these problems suddenly stopped, although it has never actually faded away. In October 2000 certain positive changes occurred in Serbia considering its international status and political convergence to the European Union, therefore, the approach to the development of the integrating processes has again been apostrophized and there are many good reasons for that (Šabić, Mihailov, 2007).

The geographical position of Serbia could be one of the advantages in the integration in the European Union. Its propitious economical position should be improved by establishing free market, but above all by defining its legal status, followed by marketing in order to create more favorable conditions than the present ones, for further economical investment. We consider that the agriculture is the safest and the most profitable sector in Serbia. Its natural conditions have enabled the development of diverse and complex forms of agricultural production, especially for growing field crops and vegetables. This is evident from the facts that $88 \%$ of agricultural land makes fields and gardens in Voivodina. Therefore, taking into account the current structure of land utilization and the natural conditions, the factors of the greatest importance are climate, soils, altitude, relief and waters, which contribute the further development of agriculture and make the basis for classification of agriculture regions in dependence on land utilization. Cultivation of crops is the predominant branch of agriculture in Serbia, both in respect of the area under these crops and total output.

The collaboration among the Balkan countries should develop not only on the national, but on the regional and particularly local level in order to motivate the citizens to participate in developing processes and directly benefit from the developing policy and integrating processes. As we already mentioned, the geographical position of Serbia enables advantageous conditions for integration. The initiative INTEREG III $\mathrm{C}$ has been started on the regional level with an aim to create institutions of influence on the trans-border zones, in which the cities would be stimulated to create their own economical expanse, infrastructure and to revitalize biotopes and sensitive ecological systems. Considering the latter it is necessary to insist on developing the trans-border spatial plans in border areas in Ser- 
bia (Šabić, Pavlović, 2008). Through the system of municipal spatial plans the local authorities should provide the following: the economical diversification strategies on the community level by developing interurban collaboration in the basic activities; the definition of the planning model based on the principles of the sustainable development, especially in the multimode transport and distribution of services and activities in the cities; integrating approach to the development of the rural and urban contact zones, i.e. development of the city and its surrounding areas; action programs for protection and revitalization of the cultural heritage in the cities and finally the promotion of the highstandard architecture.

\section{References}

Brujan, L. B. 2005. Chalenging geopolitical situations at the Eastern and Southeastern EU-border: pending problems, solutions and the future of the common European space. Serbia and modern processes in Europe and the world, Faculty of Geography, University of Belgrade, Belgrade, 146-148 pp.

Gligorov, V. et al. 1999. Balkan Reconstruction and European Integration. Meeting held in Vouliagmeni, Vouliagmeni, 5-10 pp.

Göler, D. 2005. Southeastern Europe as European Periphery, Empirical and Theoretical Aspects. Serbia and Modern Processes in Europe and the World, Faculty of Geography, University of Belgrade, Belgrade, 137-141 pp.

Grčić, M., Ratkaj, I. 2006. Transportation as a Factor of Trans-border Connection and Integration of South Eastern and the Rest of Europe. South Eastern European Coun- tries on their way to Europe - geographical aspects. Forum ifl. Leipzig: Leibniz Institut für Länderkunde. 61-74 pp.

Grčić, M., Ratkaj, I. 2003 Euro regions and Euro corridors as Integrative Factors between South Eastern Europe and European Union. Collection of the Papers, Faculty of Geography, 51, 1-22 pp. (in Serbian with English summary)

Pavlović, M. 1998. Geography of Yugoslavia II. Contemporary administration, Belgrade, $83-88$ pp. (in Serbian)

Pavlović, M., Šabić, D. 2007. Position of Serbia in Rregional Processes in the Balkans. Serbia and Republic of Srpska in Regional and Global Processes, Belgrade, Banja Luka, 43-48 pp. (in Serbian)

Stojkov, B. 2000. Regionalization Processes in the Countries of Central, East, and Southeastern Europe. Bulletin of the Serbian Geographical Society 80 (1), 59-82 pp. (in Serbian with English summary)

Šabić D., Pavlović M. 2005. Geographic Position Of Serbia, Traffic Corridors And The Integration Processes. Regions in Competition and Co-operation, Uddevalla Symposium, University of Trollhattan, Udevala, Fredrikstad, 719-728 pp.

Šabić, D., Mihailov, V. 2007. Comparative Analysis of Some Social-economic Indexes in the Development of Serbia and Bulgaria. The First Congress of Serbian Geographers. Serbian Geographical Society, Belgrade, 236 pp. (in Serbian)

Šabić, D., Pavlović, M. 2008. Global and Regional Development of the European Union. Faculty of Geography, University of Belgrade, Belgrade, 251-273 pp. (in Serbian with English summary) 